\title{
Androgen receptor activity modulates responses to cisplatin treatment in bladder cancer
}

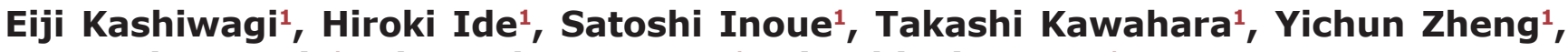 \\ Leonardo O. Reis ${ }^{1}$, Alexander S. Baras ${ }^{1}$, Hiroshi Miyamoto ${ }^{1}$ \\ ${ }^{1}$ Departments of Pathology and Urology, Johns Hopkins University School of Medicine, Baltimore, MD, USA \\ Correspondence to: Hiroshi Miyamoto, email: hiroshi_miyamoto@urmc.rochester.edu
}

Keywords: androgen receptor, bladder cancer, chemoresistance, cisplatin, NF- $\kappa B$

Received: December 23, 2015

Accepted: June 01, 2016

Published: June 14, 2016

\section{ABSTRACT}

Cisplatin (CDDP)-based combination chemotherapy remains the mainstream treatment for advanced bladder cancer. However, its efficacy is often limited due to the development of resistance for which underlying mechanisms are poorly understood. Meanwhile, emerging evidence has indicated the involvement of androgen-mediated androgen receptor (AR) signals in bladder cancer progression. In this study, we aimed to investigate whether AR signals have an impact on sensitivity to CDDP in bladder cancer cells. UMUC3-control-short hairpin RNA (shRNA) cells with endogenous AR and AR-negative 647V/5637 cells stably expressing AR were significantly more resistant to CDDP treatment at its pharmacological concentrations, compared with UMUC3-ARshRNA and 647V-vector/5637-vector control cells, respectively. A synthetic androgen R1881 significantly reduced CDDP sensitivity in UMUC3, 647V-AR, or 5637-AR cells, and the addition of an anti-androgen hydroxyflutamide inhibited the effect of R1881. In these AR-positive cells, R1881 treatment also induced the expression levels of NF-KB, which is known to involve CDDP resistance, and its phosphorylated form, as well as nuclear translocation of NF-KB. In CDDP-resistant bladder cancer sublines established following long-term culture with CDDP, the expression levels of AR as well as NF-KB and phospho-NF-KB were considerably elevated, compared with respective control sublines. In bladder cancer specimens, there was a strong trend to correlate between AR positivity and chemoresistance. These results suggest that AR activation correlates with CDDP resistance presumably via modulating NF-kB activity in bladder cancer cells. Targeting AR during chemotherapy may thus be a useful strategy to overcome CDDP resistance in patients with AR-positive bladder cancer.

\section{INTRODUCTION}

The standard of non-surgical care for bladder cancer following transurethral tumor resection includes systemic chemotherapy. Clinical studies have indeed demonstrated a survival benefit of neoadjuvant or adjuvant chemotherapy for patients with invasive bladder cancer before or after radical cystectomy $[1,2]$. Cisplatin [cisdiamminedichloroplatinum(II); CDDP]-based chemotherapy (e.g. "MVAC", "GC") also constitutes the major therapeutic option for metastatic urothelial cancer [3]. However, a significant amount of patients with bladder cancer fail to have successful responses to systemic chemotherapy. Moreover, other patients who initially respond to CDDP therapy often acquire resistance in the end. Thus, the prediction of chemosensitivity as well as the development of chemosensitization strategies constitutes a goal with critical clinical implications.

Men are approximately three times more likely to develop bladder cancer than women [4]. Emerging preclinical evidence has suggested a critical role of androgen receptor (AR) signaling in inducing urothelial carcinogenesis and cancer progression [5-18], which may explain the gender-specific difference in the incidence of bladder cancer. Retrospective cohort studies have also revealed that androgen deprivation therapy (ADT) which has been widely used for the treatment of prostate cancer prevents the development of de novo 
[19] and recurrent [20] bladder tumors in male patients. Immunohistochemical studies in bladder cancer specimens have further indicated correlations between AR expression and disease progression, while no significant difference in its levels between male and female tumors has been found $[21,22]$. Of note, androgen was recently shown to reduce sensitivity of AR-positive bladder cancer cells to doxorubicin [23], an anthracycline anti-tumor antibiotic often used for intravesical chemotherapy to prevent tumor recurrence. In addition, we have recently demonstrated, in bladder cancer cells, that androgens up-regulate ELK1 [15], a transcription factor whose downstream target is c-fos proto-oncogene, and that ELK1 inactivation results in enhancement of the cytotoxic activity of CDDP [24].

Based on these previous observations, we anticipated that AR activity could correlate with chemosensitivity. In the current study, we therefore assessed whether AR activation induced resistance to CDDP treatment in bladder cancer cells.

\section{RESULTS}

\section{AR activation correlates with resistance to CDDP}

MTT assay was used for assessing the viability of cells cultured in the presence or absence of CDDP and androgens. We first compared the cytotoxic effects of CDDP between AR-positive and AR-negative bladder cancer cell lines. CDDP inhibited cell growth in a dosedependent manner, and AR-positive cells (i.e. 647V-AR and 5637-AR with exogenous AR, UMUC3-controlshRNA with endogenous AR) were more resistant to CDDP treatment at its pharmacological concentrations (e.g. $1.3-8.4 \mu \mathrm{M}[25]$ ), compared with respective ARnegative control lines (Figure 1A). In contrast, there were no significant differences in the effects of CDDP in AR-positive versus AR-negative cells when cultured in medium supplemented with charcoal-stripped fetal bovine serum (CS-FBS) (Figure 1B). In this androgendepleted condition, however, addition of a synthetic non-metabolized androgen R1881 in medium resulted in considerable decreases in CDDP sensitivity in ARpositive cells (Figure 1C). In these assays, the effects of AR expression and/or androgen treatment on cell viability, irrespective of CDDP, were excluded by comparing with respective controls without CDDP treatment. These results suggest that AR activation reduces the cytotoxic activity of CDDP in bladder cancer cells.

To further investigate the involvement of AR signals in CDDP resistance in bladder cancer cells, we established "CDDP-resistant (CR)" sublines by long-term culture with low/increasing doses of CDDP. The growth rates of the CR sublines were similar to those of control lines cultured for the same period without CDDP (data not shown). We then confirmed lower sensitivity to CDDP in CR sublines, compared with their controls (Figure 2). Nonetheless, in these CR sublines, treatment with an anti-androgen hydroxyflutamide (HF) increased CDDP sensitivity (Figure 3). Again, in this assay, the effects of androgen/ anti-androgen treatment on cell viability, irrespective of CDDP, were excluded by comparing with respective controls without CDDP treatment.

\section{AR signaling correlates with nuclear factor (NF)-KB activity}

$\mathrm{NF}-\kappa \mathrm{B}$ activation has been implicated in acquisition of CDDP resistance [26, 27]. We therefore investigated whether androgens/AR regulate the expression and activity of $\mathrm{NF}-\kappa \mathrm{B}$ in bladder cancer cells. Western blot and real-time reverse transcription (RT)-polymerase chain reaction (PCR) showed that AR-positive lines expressed higher levels of NF- $\kappa \mathrm{B}$ protein (Figure $4 \mathrm{~A}$ ) and mRNA (Figure 4B), respectively, compared with ARnegative control lines. Similarly, in AR-positive cells, R1881 increased the expression of AR as well as that of NF- $\kappa \mathrm{B}$ and its active form, phospho-NF- $\kappa \mathrm{B}$ (p-NF$\kappa \mathrm{B})$, and $\mathrm{HF}$ at least partially abolished the effect of R1881 on their expression (Figure 5). More remarkably, immunofluorescence that was performed to determine the localization of $\mathrm{NF}-\kappa \mathrm{B}$ showed its distribution predominantly in the cytoplasm of mock-treated cells and induction of its nuclear translocation by R1881 treatment in AR-positive cells, but not in AR-negative cells (Figure 6). Thus, androgen appeared to activate NF$\kappa \mathrm{B}$ via the AR pathway in bladder cancer cells.

\section{$A R$ and $N F-\kappa B$ are up-regulated in CR cells}

We next compared the expression levels of NF- $\kappa B$ and $\mathrm{p}-\mathrm{NF}-\mathrm{\kappa B}$ as well as AR between control and CR cells. In accordance with previous findings [28], the expression of $\mathrm{NF}-\kappa \mathrm{B} / \mathrm{p}-\mathrm{NF}-\kappa \mathrm{B}$ was considerably elevated in $\mathrm{CR}$ lines, compared with respective control lines (Figure 7). Additionally, AR levels were found to be higher in 647V-AR-CR, 5637-AR-CR, and UMUC3-CR cells than in control sublines 647V-AR, 5637-AR, and UMUC3, respectively. These results suggest the involvement of $A R$ in CDDP resistance in bladder cancer cells.

\section{Correlations of AR/NF- $\kappa \mathrm{B} / \mathrm{p}-\mathrm{NF}-\kappa \mathrm{B}$ expression with chemoresistance in bladder cancer patients}

Finally, we immunohistochemically stained for AR, $\mathrm{NF}-\kappa \mathrm{B}$, and $\mathrm{p}-\mathrm{NF}-\kappa \mathrm{B}$ in our tissue microarrays (TMAs) consisting of muscle-invasive bladder cancer specimens from patients who subsequently received neoadjuvant GC therapy (Figure 8). We then compared their expression levels between responders versus non-responders to chemotherapy (Table 1). Overall, AR was positive in 19 $(35 \%)$ of 55 cases, including 5 (21\%) of 24 responders 
Table 1: The expression of $\mathrm{AR}, \mathrm{NF}-\kappa \mathrm{B}$, and $\mathrm{p}-\mathrm{NF}-\kappa \mathrm{B}$ in bladder cancer and response to chemotherapy

\begin{tabular}{|c|c|c|c|c|c|c|c|c|c|c|c|c|c|c|c|c|}
\hline & \multirow[b]{2}{*}{$n$} & \multicolumn{4}{|c|}{ AR expression } & \multirow[b]{2}{*}{$P$} & \multicolumn{4}{|c|}{ NF-кB expression } & \multirow[b]{2}{*}{$P$} & \multicolumn{4}{|c|}{ p-NF-кB expression } & \multirow[b]{2}{*}{$P$} \\
\hline & & $0(\%)$ & $1+(\%)$ & $2+(\%)$ & $3+(\%)$ & & $0(\%)$ & $1+(\%)$ & $2+(\%)$ & $3+(\%)$ & & $0(\%)$ & $1+(\%)$ & $2+(\%)$ & $3+(\%)$ & \\
\hline All patients & 55 & & & & & & & & & & & & & & & \\
\hline Responders & 24 & $19(79)$ & $3(13)$ & $0(0)$ & $2(8)$ & \multirow{2}{*}{$0.087^{\mathrm{a}}$} & $0(0)$ & $7(29)$ & $11(46)$ & $6(25)$ & \multirow{2}{*}{$\begin{array}{l}0.525^{b} \\
0.162^{\mathrm{c}}\end{array}$} & $11(46)$ & $7(29)$ & $5(21)$ & $1(4)$ & \multirow{2}{*}{$0.044^{\mathrm{a}}$} \\
\hline Non-Responders & 31 & $17(55)$ & $13(42)$ & $1(3)$ & $0(0)$ & & $0(0)$ & $6(19)$ & $11(35)$ & $14(45)$ & & $6(19)$ & $15(48)$ & $8(26)$ & $2(6)$ & \\
\hline Male patients & 45 & & & & & & & & & & & & & & & \\
\hline Responders & 19 & $15(78)$ & $2(11)$ & $0(0)$ & $2(11)$ & \multirow{2}{*}{$0.118^{\mathrm{a}}$} & $0(0)$ & $5(26)$ & $9(47)$ & $5(26)$ & $0.720^{\mathrm{b}}$ & $8(42)$ & $6(32)$ & $4(21)$ & $1(5)$ & \multirow{2}{*}{$0.111^{\mathrm{a}}$} \\
\hline Non-Responders & 26 & $14(54)$ & $11(42)$ & $1(4)$ & $0(0)$ & & $0(0)$ & $5(19)$ & $9(35)$ & $12(46)$ & $0.222^{\mathrm{c}}$ & $5(19)$ & $13(50)$ & $6(23)$ & $2(8)$ & \\
\hline Female patients & 10 & & & & & & & & & & & & & & & \\
\hline Responders & 5 & $4(80)$ & $1(20)$ & $0(0)$ & $0(0)$ & \multirow{2}{*}{$1.000^{\mathrm{a}}$} & $0(0)$ & $2(40)$ & $2(40)$ & $1(20)$ & $1.000^{\mathrm{b}}$ & $3(60)$ & $1(20)$ & $1(20)$ & $0(0)$ & \multirow{2}{*}{$0.524^{\mathrm{a}}$} \\
\hline Non-Responders & 5 & $3(60)$ & $2(40)$ & $0(0)$ & $0(0)$ & & $0(0)$ & $1(20)$ & $2(40)$ & $2(40)$ & $1.000^{\mathrm{c}}$ & $1(20)$ & $2(40)$ & $2(40)$ & $0(0)$ & \\
\hline
\end{tabular}

${ }^{\mathrm{a}} 0 v_{s} .1+/ 2+/ 3+$

${ }^{\mathrm{b}} 0 / 1+v s .2+/ 3+$

${ }^{\mathrm{c}} 0 / 1+/ 2+v s .3+$

A
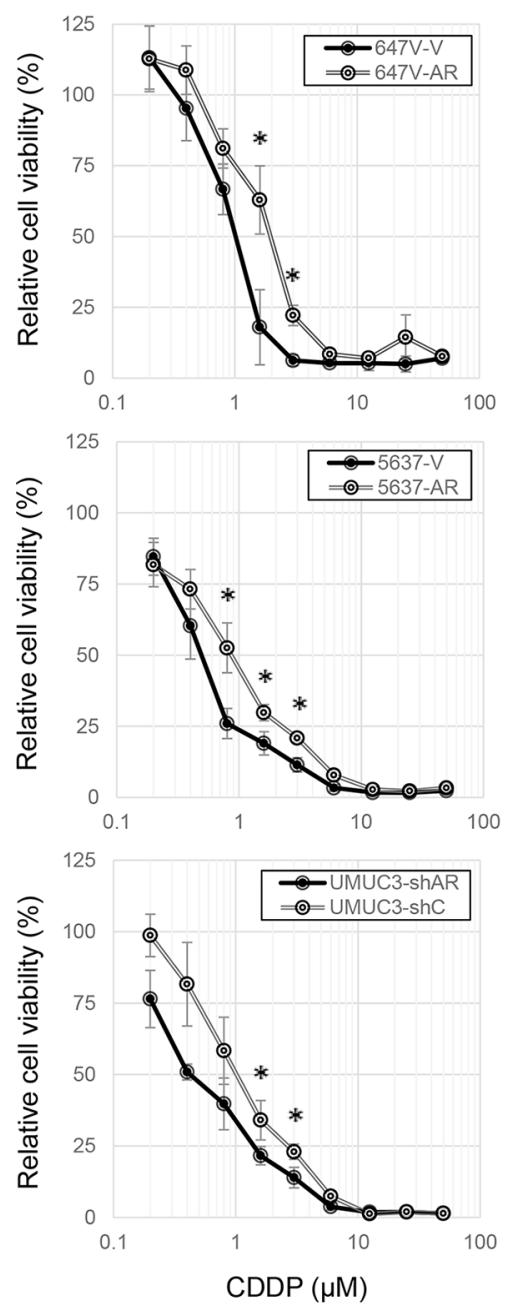

B
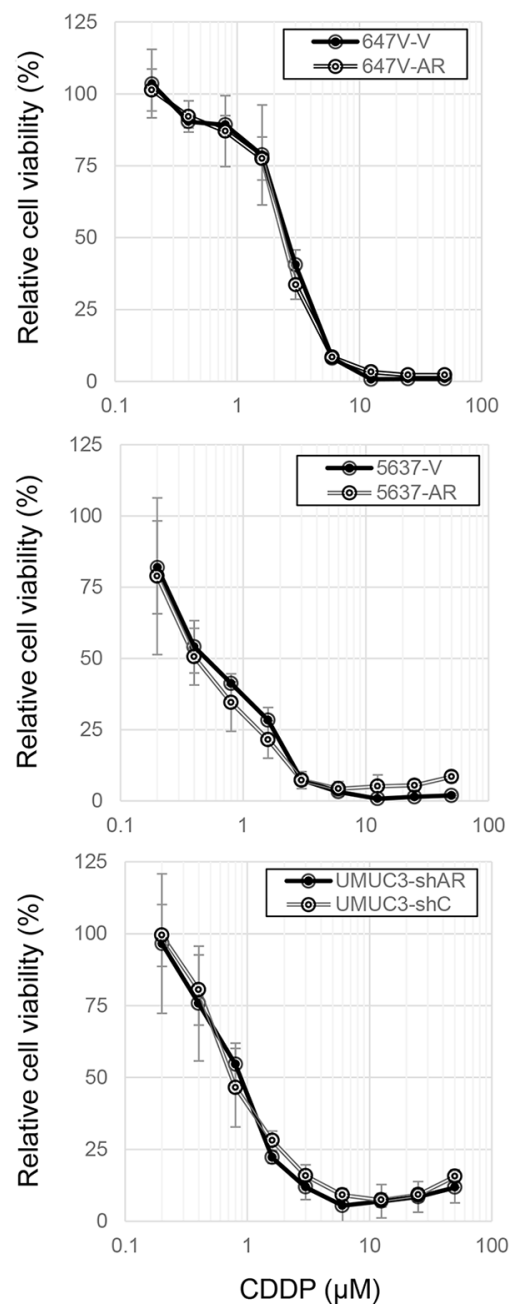

C (CS-FBS + R1881)
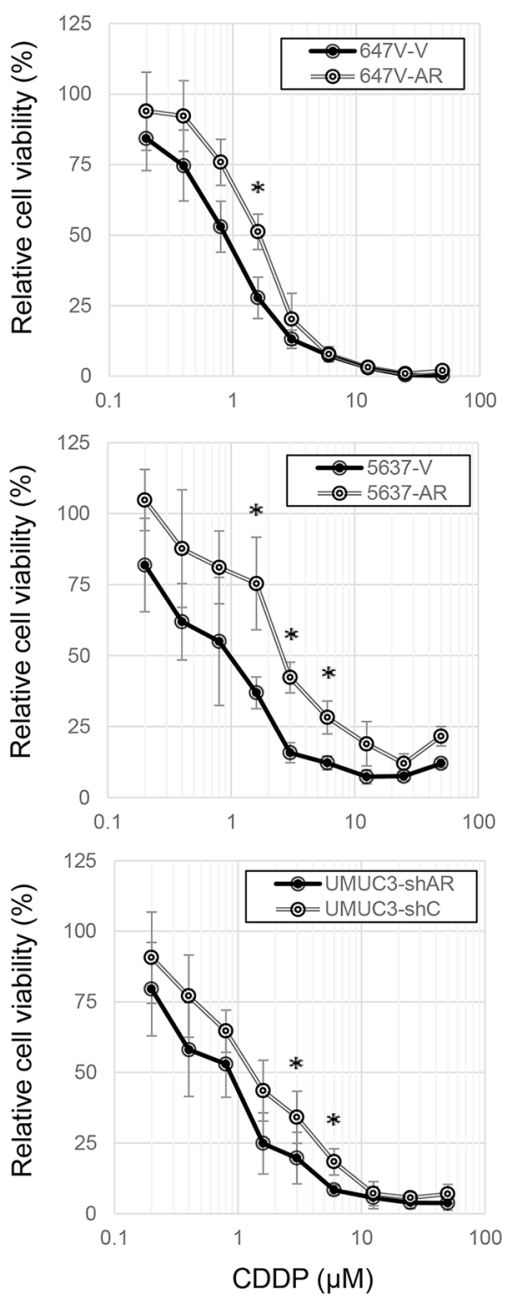

Figure 1: Effects of AR expression on the cytotoxicity of CDDP in bladder cancer cells. MTT assay was performed in 647VV/AR, 5637-V/AR, and UMUC3-control-shRNA (shC)/AR-shRNA (shAR) cells cultured in medium containing (A) 10\% normal FBS, (B) $10 \%$ CS-FBS, or (C) 10\% CS-FBS + $10 \mathrm{nM}$ R1881, as well as different concentrations $(0.2-50 \mu \mathrm{M})$ of CDDP for $72 \mathrm{~h}$. Cell viability is presented relative to that of each line without CDDP treatment. Each value represents the mean $( \pm$ SD) from at least three independent experiments. ${ }^{*} P<0.05$ (647V-V vs. 647V-AR, 5637-V vs. 5637-AR, or UMUC3-control-shRNA vs. UMUC3-AR-shRNA). 
and 14 (45\%) of 31 non-responders. Thus, AR positivity tended to correlate with resistance to chemotherapy $(P=0.087)$. These patients with AR-positive tumor included $22 \%$ of male responders $v s$. $46 \%$ of male nonresponders and $20 \%$ of female responders vs. $40 \%$ of female non-responders. More strikingly, there was a strong correlation between $\mathrm{p}-\mathrm{NF}-\kappa \mathrm{B}$ positivity and chemotherapy resistance (54\% of responders vs. $81 \%$ of non-responders; $P=0.044)$. However, there was no statistically significant difference in NF- $\kappa \mathrm{B}$ levels between responders and nonresponders. In addition, the expression of AR and p-NF- $\kappa \mathrm{B}$ in these 55 tumors was marginally correlated $(P=0.078)$, while strong $(3+)$ positivity of $\mathrm{NF}-\kappa \mathrm{B}$ was significantly associated with $\mathrm{p}-\mathrm{NF}-\kappa \mathrm{B}$ expression $(P=0.002)$.

\section{DISCUSSION}

CDDP has been widely used for the treatment of solid malignancies, including bladder cancer. Meanwhile, underlying reasons for CDDP resistance have been extensively explored, using a variety of models of CDDP- sensitive vs. CDDP-resistant cancer cells, leading to identification of multifactorial mechanisms, including drug transport, accumulation, detoxification, DNA repair, transcription, and apoptosis [29-31]. Thus, molecular mechanisms responsible for CDDP resistance appear to be complicated. In the current study, we provide preclinical evidence indicating that AR activation solely results in induction of CDDP resistance in bladder cancer cells. These findings further suggest not only that AR expression may predict response to CDDP treatment but also that anti-androgenic drugs may function as sensitizers.

Preclinical findings have suggested that ADT inhibits the growth of AR-positive bladder cancer [5-10, 13, 14, 16-18]. A previous study also demonstrated that addition of dihydrotestosterone in androgen-depleted culture medium resulted in reduction of the cytotoxic effect of doxorubicin on AR-positive bladder cancer cell proliferation [23]. Similarly, in a renal pelvic urothelial carcinoma line cultured with doxorubicin or CDDP, enforced expression of AR was shown to increase cell viability, whereas CDDP cytotoxicity was not directly
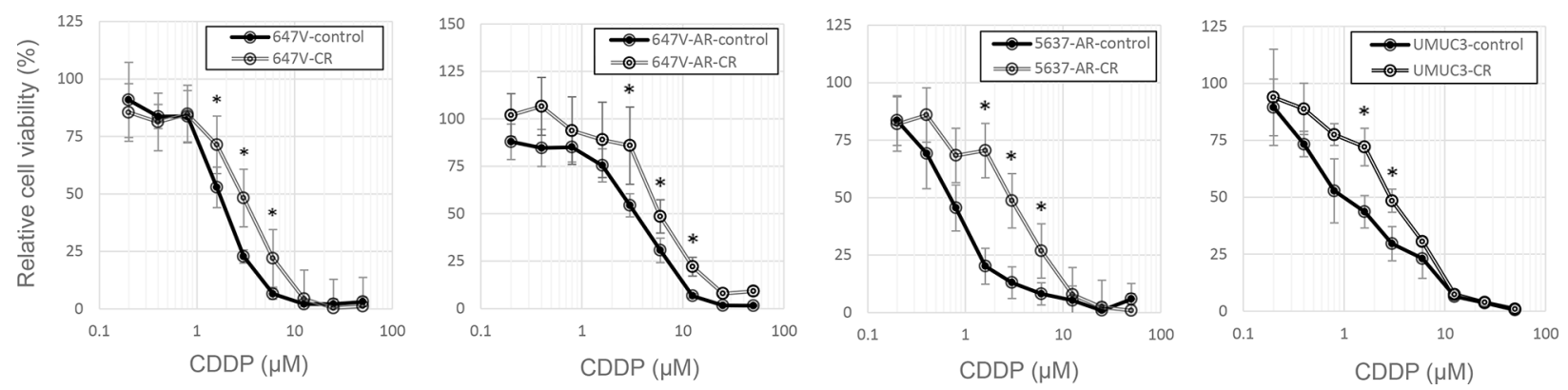

Figure 2: Establishment of CR sublines. MTT assay was performed in 647V-control/CR, 647V-AR-control/CR, 5637-AR-control/ $\mathrm{CR}$, and UMUC3-control/CR cells cultured in medium containing $10 \%$ FBS as well as different concentrations $(0.2-50 \mu \mathrm{M})$ of CDDP for $72 \mathrm{~h}$. Cell viability is presented relative to that of each line without CDDP treatment. Each value represents the mean ( \pm SD) from at least three independent experiments. ${ }^{*} P<0.05$ (647V-control vs. 647V-CR, 647V-AR-control vs. 647V-AR-CR, 5637-AR-control vs. 5637-ARCR, or UMUC3-control vs. UMUC3-CR).

\section{V-AR-CR}

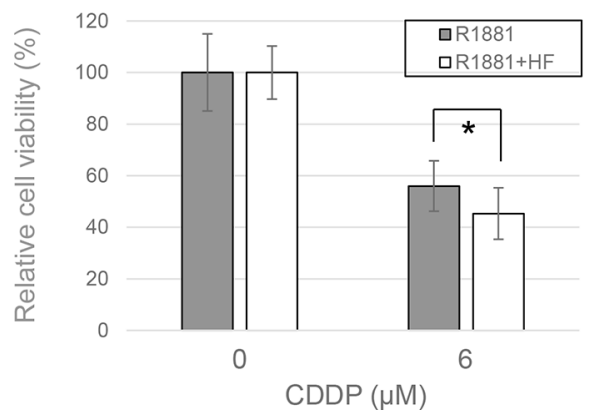

5637-AR-CR

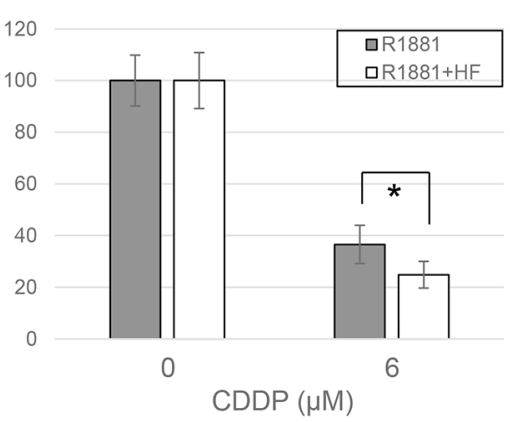

UMUC3-CR

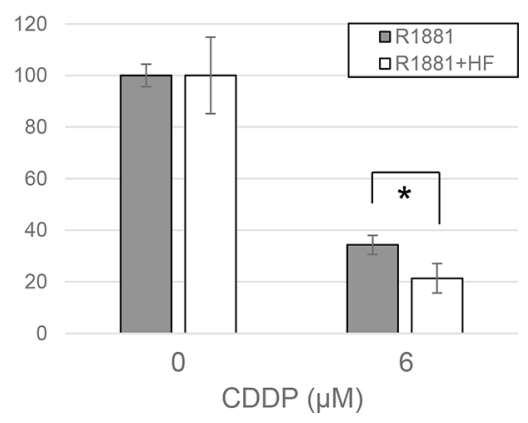

Figure 3: Effects of anti-androgen on the cytotoxicity of CDDP in CR bladder cancer cells cultured with androgen. MTT assay was performed in 647V-AR-CR, 5637-AR-CR, and UMUC3-CR cells cultured in medium containing $10 \%$ CS-FBS, $10 \mathrm{nM}$ $\mathrm{R} 1881$, either ethanol or $5 \mu \mathrm{M} \mathrm{HF}$, and either ethanol or $6 \mu \mathrm{M}$ CDDP for $72 \mathrm{~h}$. Cell viability is presented relative to that of each line without $\mathrm{CDDP}$ treatment. Each value represents the mean $( \pm \mathrm{SD})$ from at least three independent experiments. $* P<0.05(\mathrm{R} 1881 v s . \mathrm{R} 1881+\mathrm{HF}$ in each cell line). 
compared between these AR-positive versus AR-negative cells [32]. We further found that AR inactivation could increase sensitivity to CDDP in bladder cancer cells. Thus, the roles of ADT in the treatment of bladder cancer, especially in male patients, may be two-fold direct inhibition of tumor outgrowth and enhancement of chemosensitivity. Accordingly, an additive or synergistic effect of ADT and CDDP-based chemotherapy is expected.

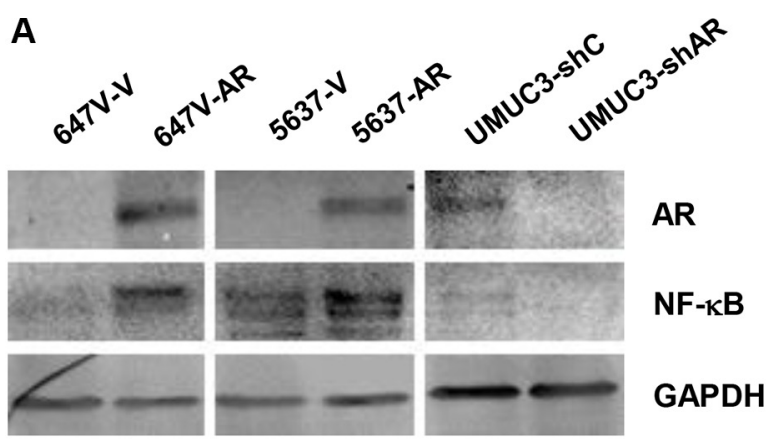

B
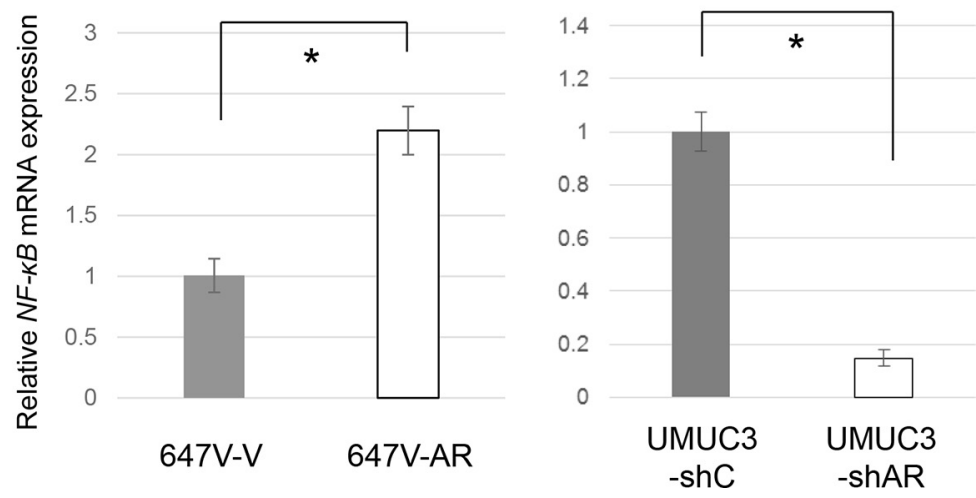

Figure 4: Effects of AR on NF-KB expression in bladder cancer cells. (A) Western blotting of $A R$ and NF- $\kappa B$ in $647 \mathrm{~V}-\mathrm{V} / \mathrm{AR}$, 5637-V/AR, and UMUC3-control-shRNA (shC)/AR-shRNA (shAR) cells. Total protein extracted from each line was immunoblotted for AR (110 kDa), NF- $\mathrm{kB}(65 \mathrm{kDa})$. GAPDH (37 kDa) served as an internal control. (B) Quantitative RT-PCR of $N F-\kappa B$ in $647 \mathrm{~V}-\mathrm{V} / \mathrm{AR}$ and UMUC3-control-shRNA (shC)/AR-shRNA (shAR) cells. Each line was subjected to RNA extraction and subsequent real-time RT-PCR. Expression of $N F-\kappa B$ gene was normalized to that of GAPDH. Transcription amount is presented relative to that of each control line. Each value represents the mean $(+\mathrm{SD})$ from at least three independent experiments. ${ }^{*} P<0.05(647 \mathrm{~V}-\mathrm{V} v s .647 \mathrm{~V}$-AR or UMUC3-control-shRNA vs. UMUC3-AR-shRNA).

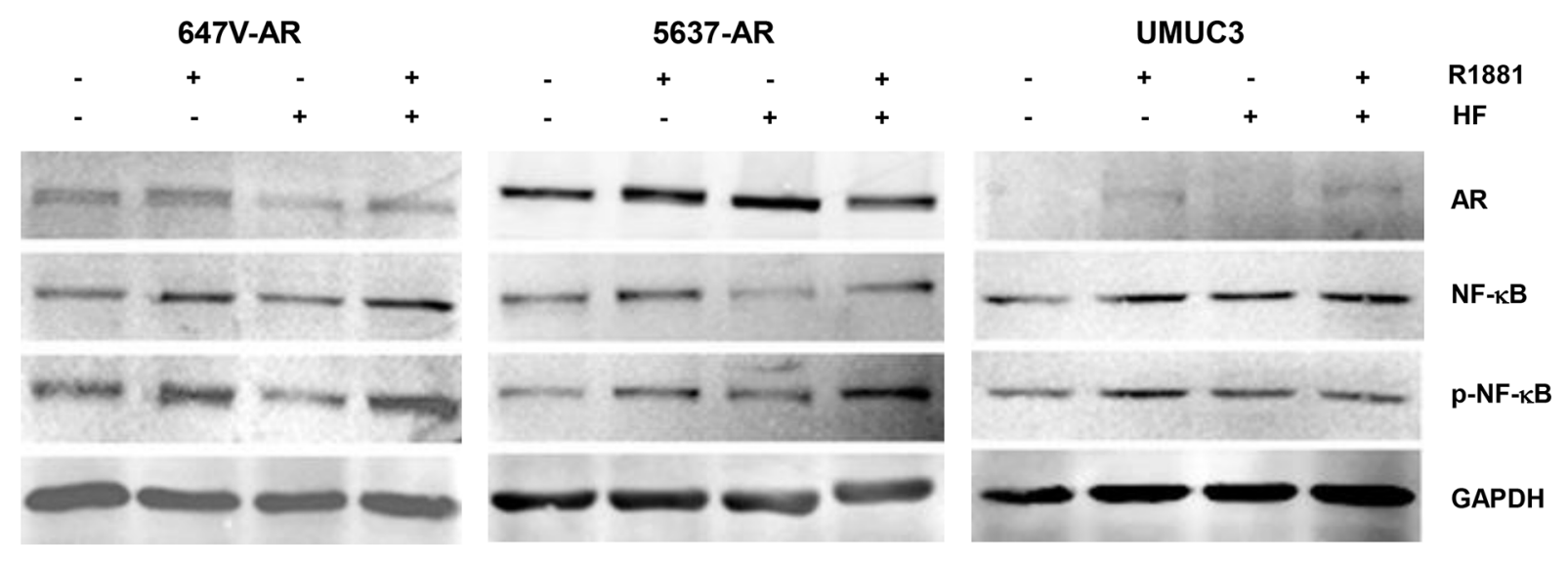

Figure 5: Effects of androgen on NF- $\mathbf{B}$ expression in bladder cancer cells. Western blotting of $A R, N F-\kappa B$, and $p-N F-\kappa B$ in

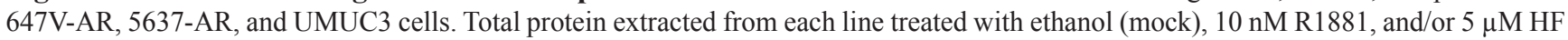

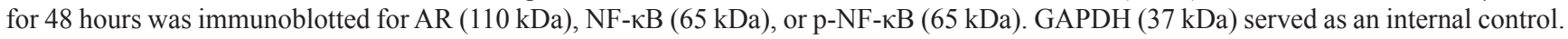



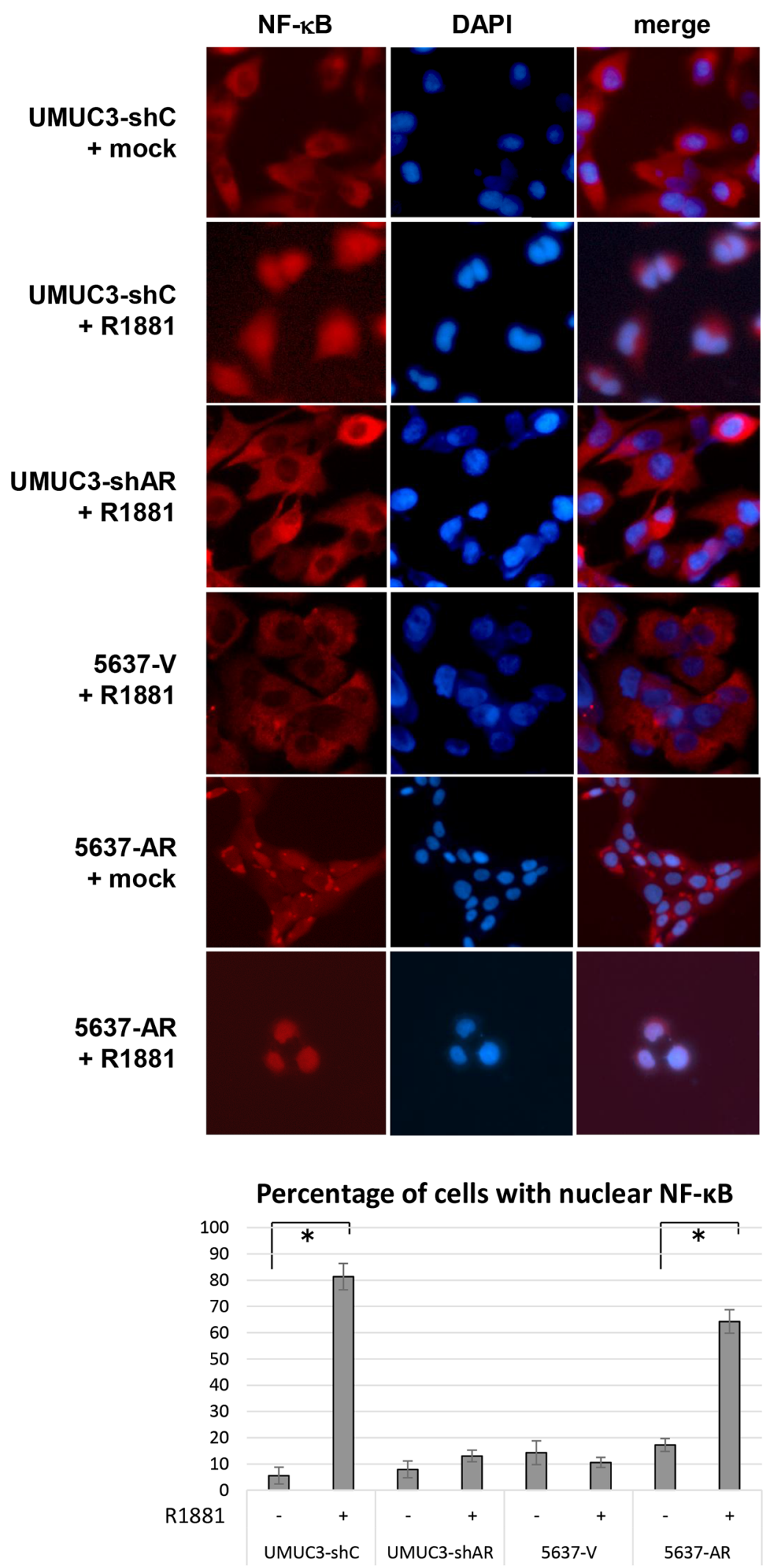

Figure 6: Effects of androgen on nuclear translocation of NF- $\mathbf{B}$ in bladder cancer cells. UMUC3-control-shRNA (shC)/ AR-shRNA (shAR) and 5637-V/AR cells treated with ethanol (mock) or $10 \mathrm{nM} \mathrm{R} 1881$ for $24 \mathrm{~h}$ were analyzed on immunofluorescence, using an antibody to NF- $\kappa$ B. DAPI was used to visualize nuclei. The number of nuclear staining per visual field was quantified in five randomly selected visual fields per chamber. Each value represents the mean $(+\mathrm{SD})$ from at least three independent experiments. ${ }^{*} P<0.05$ (mock vs. R1881). 
It has been shown that the levels of AR expression are significantly lower in bladder tumors than in nonneoplastic urothelial tissues as well as in high-grade/ muscle-invasive bladder carcinomas than in low-grade/ superficial tumors [21, 22]. Nonetheless, AR positivity in bladder tumors, especially in muscle-invasive carcinomas, has been associated with worse patient outcomes $[8,21]$. On the other hand, none of previous studies have revealed a significant difference in the levels of AR expression between male versus female bladder tumors [22], while it remains unclear whether low levels of androgens significantly activate AR in, for instance, female tumors. In bladder cancer cell lines resistant to doxorubicin, AR expression was shown to be elevated [23]. We additionally found considerable increases in AR expression in CR lines, compared with respective control lines. Furthermore, in transurethral resection specimens from patients who underwent CDDP-based neoadjuvant chemotherapy prior to cystectomy, we detected a trend toward significance between AR expression and chemoresistance. Specifically, 22\% of male responders versus $46 \%$ of male non-responders had AR-positive tumors. Thus, the status of AR expression, together with the levels of serum androgens, may serve as a predictor of chemosensitivity. In our staining, however, the degree of AR expression did not appear to have an influence on likelihood of chemoresistance, implying that the presence of a functional AR in tumor cells is critical and may suffice for inducing drug resistance. Further studies, including larger patient cohort and those who receive CDDP therapy in adjuvant settings, are needed to validate the current results. Interestingly, AR signals have also been shown to induce radioresistance in prostate cancer cells by regulating DNA repair genes that are also known to contribute to CDDP resistance [33] and the expression of $\mathrm{ABCG} 2$, a membrane transporter protein associated

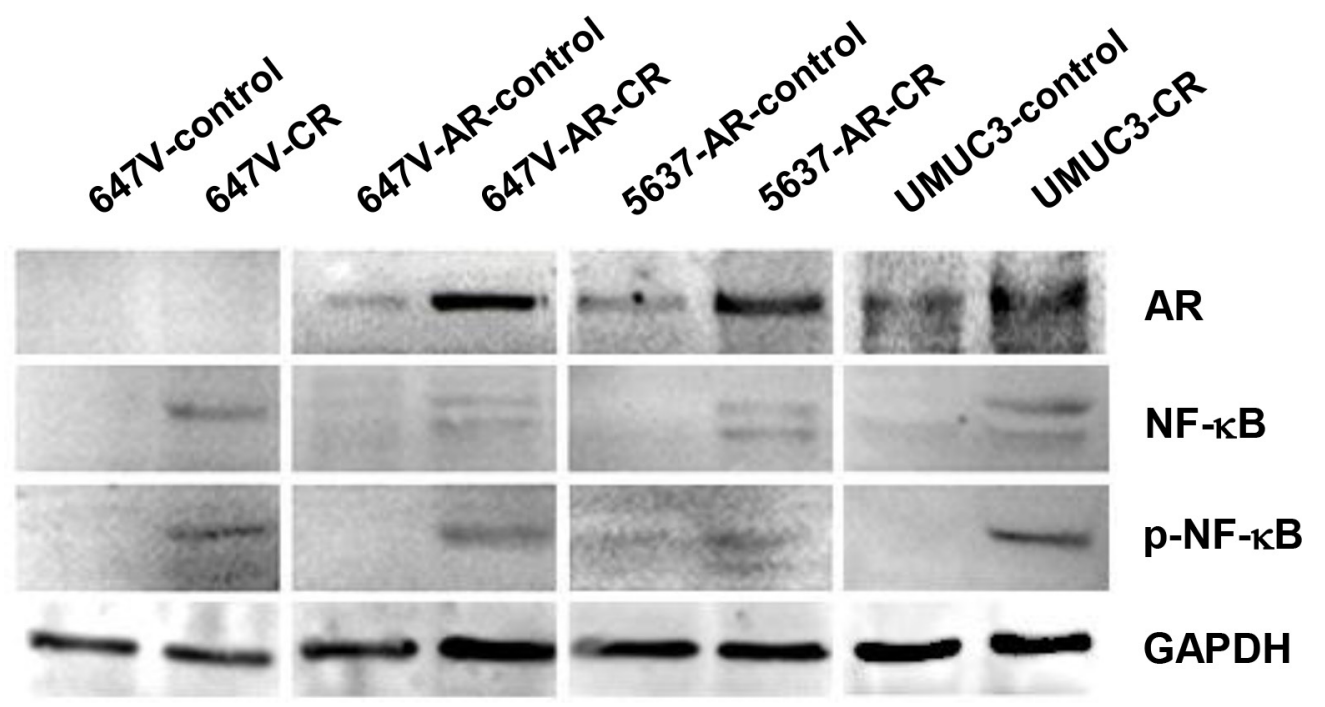

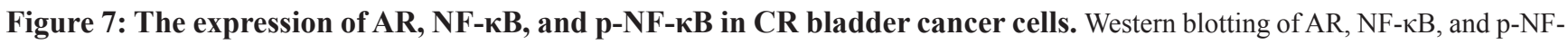
$\kappa \mathrm{B}$ in $647 \mathrm{~V}$-control/CR, 647V-AR-control/CR, 5637-AR-control/CR, and UMUC3-control/CR cells. Total protein extracted from each line

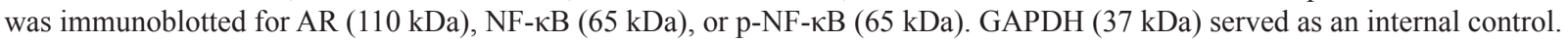
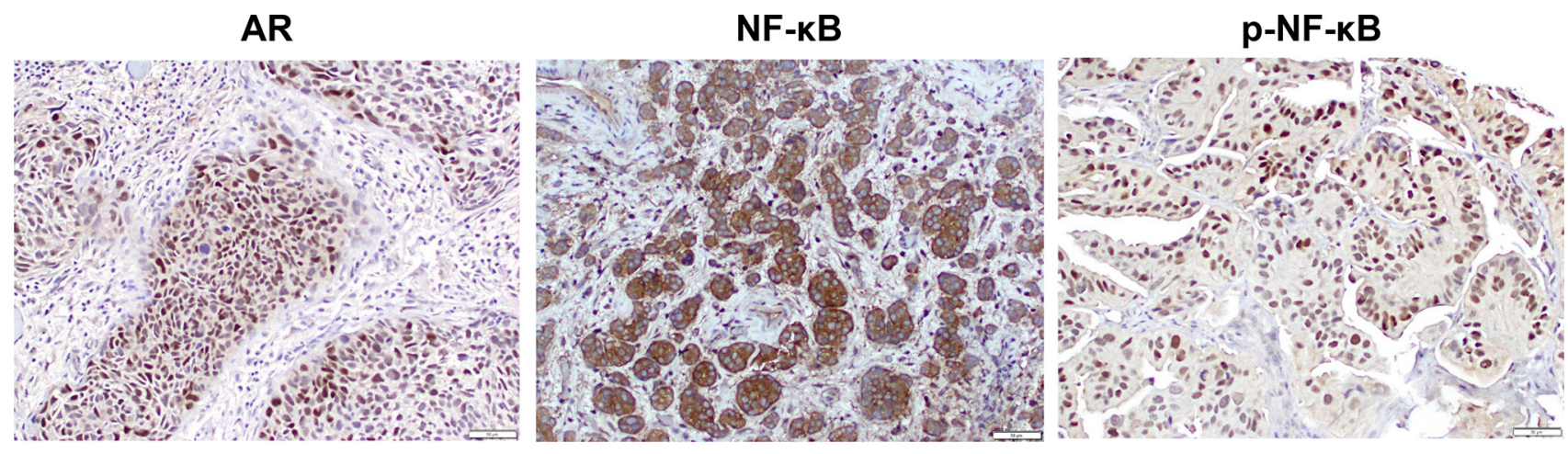

Figure 8: The expression of $\mathbf{A R}, \mathbf{N F - \kappa B}$, and $\mathbf{p}-\mathbf{N F}-\kappa \mathrm{B}$ in human bladder cancer specimens. Immunohistochemistry of $\mathrm{AR} / \mathrm{p}-\mathrm{NF}-\kappa \mathrm{B}$ and NF- $\mathrm{kB}$ in bladder TMAs for which tissue specimens were collected prior to chemotherapy shows strong signals predominantly in the nucleus and cytoplasm, respectively, of tumor cells. 
with multidrug resistance, in upper urinary tract urothelial carcinoma cells [32].

$\mathrm{NF}-\kappa \mathrm{B}$ that normally resides in the cytoplasm as an inactivated form translocates to the nucleus and thereby activates its target genes involving cell proliferation/ apoptosis, angiogenesis, and cell invasion. In prostate cancer [34, 35] and endothelial [36] cells, androgens have been shown to activate NF- $\kappa \mathrm{B}$. Signaling crosstalk between $\mathrm{NF}-\kappa \mathrm{B}$ and AR has also been suggested [34, $36-38]$. In particular, the p65/p50 subunit of $N F-\kappa B$, as a complex with tissue transglutaminase, is able to bind to the $\mathrm{AR}$ promoter at $\mathrm{NF}-\kappa \mathrm{B}$ response element sites in prostate cancer cells [38]. We here showed that androgen induced the expression of $\mathrm{NF}-\kappa \mathrm{B} / \mathrm{p}-\mathrm{NF}-\kappa \mathrm{B}$ and nuclear translocation of NF- $\kappa \mathrm{B}$ in bladder cancer cells.

$\mathrm{NF}-\kappa \mathrm{B}$, as a transcription factor that induces antiapoptotic proteins, has been considered as a key molecule for CDDP resistance [26-28]. Correspondingly, our immunohistochemistry indicated the relationship between the positivity of $\mathrm{p}-\mathrm{NF}-\kappa \mathrm{B}$, but not the degree of $\mathrm{p}-\mathrm{NF}-\kappa \mathrm{B}$ or $\mathrm{NF}-\kappa \mathrm{B}$ expression, and chemoresistance. Inhibitors, including dehydroxymethylepoxyquinomicin that prevents nuclear translocation of $\mathrm{NF}-\kappa \mathrm{B}$ and its binding to DNA, have indeed been reported to not only exhibit anti-cancer activity but also confer sensitization to CDDP in CR cells [39]. However, the precise molecular mechanisms of how NF- $\kappa \mathrm{B}$ signals regulate CDDP sensitivity remain far from fully understood, although $\mathrm{NF}-\kappa \mathrm{B}$ is known to regulate tumor cell sensitivity to drug-induced apoptosis. Potentially key mechanisms include activation of the antiapoptotic bcl-2 family [40], MEKK1-mediated activation of c-JUN [41], up-regulation of anti-apoptotic c-FLIP [28], and histone modifications [42]. As aforementioned, multifactorial pathways are likely to involve CDDP resistance [29-31], and, in some of these, NF- $\kappa \mathrm{B}$ may not necessarily be a central player. For instance, we have demonstrated activation of ERBB2 [8] and ELK1 [16], both of which have also been shown to induce CDDP resistance [24, 30, 31], by androgens in AR-positive bladder cancer cells.

In contrast to our current findings, in a study where the effects of androgen treatment and AR silencing on cytotoxicity of doxorubicin, 5-fluorouracil, and CDDP in bladder cancer cells were examined, androgen failed to modulate sensitivity to CDDP [23]. Differences between the previous [23] versus current studies included treatment of $1 \mathrm{nM}$ dihydrotestosterone for 48 hours versus that of 10 nM R1881 for 72 hours as well as transient expression of AR-small interfering RNA versus stable expression of ARshRNA, while UMUC3 cells were used in both studies. These differences might be relevant to the inconsistent results. Additionally, in the previous study [23], androgen did not reduce the cytotoxic activity of 5-fluorouracil. Using the same models for bladder cancer for assessing cytotoxicity of CDDP, we investigated the role of AR signals in sensitivity of gemcitabine and found no significant effects of AR overexpression or silencing (data not shown). Thus, $\mathrm{NF}-\kappa \mathrm{B}$ appears to play an insignificant role in AR-induced gemcitabine resistance, if any, in bladder cancer cells. Nonetheless, NF- $\kappa \mathrm{B}$ activation was shown to be a basis for gemcitabine resistance in pancreatic cancer cells [43].

In conclusion, we demonstrate preclinical evidence indicating that $\mathrm{AR}$ activation contributes to $\mathrm{CDDP}$ resistance in bladder cancer cells presumably via $N F-\kappa B$ activation. Therefore, patients with AR-negative and $\mathrm{p}-\mathrm{NF}$ $\kappa \mathrm{B}$-negative tumor are more likely to respond to CDDPbased chemotherapy. In contrast, those with AR-positive or $\mathrm{p}-\mathrm{NF}-\kappa \mathrm{B}$-positive tumor may be resistant to CDDP therapy and are anticipated to benefit from combined antiAR therapy. Thus, depending on the gender and hormone milieu of the patients as well as AR expression profile in the tumors, comedication with ADT may be useful for overcoming chemoresistance. Further investigations are required to determine the effects of anti-AR therapy on chemosensitivity, especially in animal models for bladder cancer, and to elucidate the precise mechanisms of how AR signals involve CDDP resistance in bladder cancer cells.

\section{MATERIALS AND METHODS}

\section{Antibodies and chemicals}

Anti-AR (N-20), anti-NF-кB (sc-109), and antiGAPDH (6c5) antibodies and an anti-p-NF- $\mathrm{B}$ antibody (Ser536) were purchased from Santa Cruz Biotechnology and Cell Signaling Technology, respectively. We obtained methyltrienolone (R1881) from PerkinElmer, and HF and CDDP from Sigma-Aldrich.

\section{Cell lines}

Human urothelial carcinoma cell lines, UMUC3 and 5637, were originally obtained from the American Type Culture Collection (Manassas, VA). Another human urothelial carcinoma cell line, $647 \mathrm{~V}$, was used in our previous studies [5, 15-18, 24, 44]. All these lines were recently authenticated, using GenePrint 10 System (Promega), by the institutional core facility.

Cell lines stably expressing a full-length wild-type human AR (5637-AR and 647V-AR) or vector only (5637$\mathrm{V}$ and $647 \mathrm{~V}-\mathrm{V})$ were established, using a lentivirus vector (pWPI-AR or pWPI-control) with psPAX2 envelope and pMD2.G packaging plasmids, as we described previously $[8,15]$. Similarly, stable AR knockdown/control cell lines [UMUC3-AR-short hairpin RNA (shRNA)/UMUC3control-shRNA] were established, using a retrovirus vector pMSCV/U6-AR-shRNA or pMSCV/U6-control-shRNA [8].

CDDP-resistant cell lines, 647V-CR, 647V-AR-CR, 5637-AR-CR, and UMUC3-CR, were then established from 647V, 647V-AR, 5637-AR, and UMUC3 cells, respectively, by stepwise, continuous treatment with CDDP (e.g. 0.2-2.0 $\mu \mathrm{M})$ for at least 12-weeks. 
All these cell lines were maintained in Dulbecco's modified Eagle's medium (Mediatech) supplemented with $10 \% \mathrm{FBS}$ at $37^{\circ} \mathrm{C}$ in a humidified atmosphere of $5 \%$ $\mathrm{CO} 2$. Cells were then cultured in phenol red-free medium supplemented with either $10 \%$ FBS or $10 \%$ CS-FBS at least 24 hours before experimental treatment.

\section{Western blot}

Equal amounts of proteins obtained from cell extracts were subjected to sodium dodecyl sulfatepolyacrylamide gel electrophoresis, transferred to polyvinylidene difluoride membranes electronically, blocked, and incubated with a specific primary antibody. The membrane was then incubated with a secondary antibody, and specific signals were detected, using a LICOR imaging system.

\section{MTT assay}

We used the MTT (thiazolyl blue) assay to assess cell viability, as described previously [15], with minor modifications. Briefly, cells $\left(2-6 \times 10^{3}\right)$ seeded in 96-well plates were cultured for $72 \mathrm{~h}$ in the presence or absence of CDDP and then incubated with $0.5 \mathrm{mg} / \mathrm{mL}$ of MTT (Sigma) in $100 \mu \mathrm{L}$ of medium for $3 \mathrm{~h}$ at $37^{\circ} \mathrm{C}$. MTT was solved by DMSO, and the absorbance was measured at a wavelength of $570 \mathrm{~nm}$ with background subtraction at $630 \mathrm{~nm}$.

\section{RT and real-time PCR}

Total RNA isolated from cultured cells by TRIzol (Invitrogen, Carlsbad, CA) was reverse transcribed, using $1 \mu \mathrm{mol} / 1$ oligo(dT) primers and four units of Ominiscript reverse transcriptase (Qiagen). Real-time PCR was then performed, using RT2 SYBR Green FAST Mastermix (Qiagen), as described previously [16]. The primer sequences are: 5'-AACAGAGAGGATTTCGTTTCC-3' (forward) and 5'-TTTGACCTGAGGGTAAGACTTCT-3' (reverse)

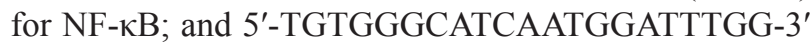
(forward) and 5'-ACACCATGTATTCCGGGTCAAT -3' (reverse) for GAPDH.

\section{Immunofluorescent staining}

Immunofluorescent staining was performed, as described previously [13, 16, 44], with minor modifications. Briefly, cells plated onto chamber slides (8-well Nunc Lab-Tek, Thermo Scientific) were cultured in medium containing ethanol or R1881 for $24 \mathrm{~h}$, and the adherent cells were fixed with $4 \%$ paraformaldehyde. After being blocked, a primary antibody $(\mathrm{NF}-\kappa \mathrm{B})$ was incubated at $4{ }^{\circ} \mathrm{C}$ overnight, and Alexa 488 conjugated secondary antibody (diluted 1:500, Invitrogen) was added for $1 \mathrm{~h}$ at $37^{\circ} \mathrm{C}$. Fluorescence images were acquired with an Olympus FV1000 confocal microscope and nuclear expression of the proteins was quantified by a single observer who was unaware of the treatment group for the cells.

\section{Immunohistochemistry}

We retrieved bladder tissue specimens obtained by transurethral resection for TMA construction. Appropriate approval from the institutional review board was obtained before construction and use of the TMAs. These bladder TMAs constructed previously [21, 24, 45] included cases of high-grade muscle-invasive urothelial carcinoma that received GC neoadjuvant chemotherapy prior to radical cystectomy. Patients who received only 3 cycles of GC with dose reduction or $\leq 2$ cycles of GC were excluded from the analysis. Responders $(n=24)$ and non-responders $(n=31)$ to the neoadjuvant therapy were pathologically defined as the absence $(\leq \mathrm{pT} 1 \mathrm{~N} 0 \mathrm{M} 0)$ and presence $(\geq \mathrm{pT} 2, \mathrm{pN} 1-3$, and/or M1), respectively, of muscleinvasive, extravesical, or metastatic disease at the time of cystectomy [46].

Immunohistochemistry was performed on the sections ( $5 \mu \mathrm{m}$ thick) from the bladder TMAs, using a primary antibody to AR (dilution 1:200), NF- $\mathrm{KB}$ (dilution

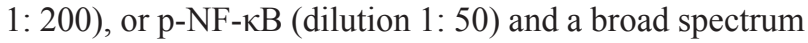
secondary antibody (Invitrogen), as described previously $[8,21]$. All stains were manually quantified by a single pathologist (H.M.) blinded to sample identify. The German immunoreactive scores calculated by multiplying the percentage of immunoreactive cells $(0 \%=0 ; 1-10 \%=1$; $11-50 \%=2 ; 51-80 \%=3 ; 81-100 \%=4)$ by staining intensity (negative $=0 ;$ weak $=1 ;$ moderate $=2 ;$ strong $=3$ ) were considered negative $(0 ; 0-1)$, weakly positive $(1+$; $2-4)$, moderately positive $(2+; 6-8)$, and strongly positive (3+; 9-12).

\section{Statistical analysis}

Student's $t$-test was used to analyze differences in variables with a continuous distribution. The Fisher exact test or chi-square test was used to evaluate the associations between categorized variables. $P$ values less than 0.05 was considered statistically significant.

\section{CONFLICTS OF INTEREST}

The authors have no conflicts of interest to disclose.

\section{REFERENCES}

1. Keegan KA, Zaid HB, Patel SG, Chang SS. Increasing utilization of neoadjuvant chemotherapy for muscleinvasive bladder cancer in the United States. Curr Urol Rep. 2014; $15: 394$.

2. Leow JJ, Martin-Doyle W, Rajagopal PS, Patel CG, Anderson EM, Rothman AT, Cote RJ, Urun Y, Chang SL, Choueiri TK, Bellmunt J. Adjuvant chemotherapy for invasive 
bladder cancer: a 2013 updated systematic review and metaanalysis of randomized trials. Eur Urol. 2014; 66:42-54.

3. von der Maase H, Sengelov L, Roberts JT, Ricci S, Dogliotti L, Oliver T, Moore MJ, Zimmermann A, Arning M. Long-term survival results of a randomized trial comparing gemcitabine plus cisplatin, with methotrexate, vinblastine, doxorubicin, plus cisplatin in patients with bladder cancer. J Clin Oncol. 2005; 23:4602-4608.

4. Siegel R, Miller KD, Jemal A. Cancer statistics, 2015. CA Cancer J Clin. 2015; 65:5-29.

5. Miyamoto H, Yang Z, Chen YT, Ishiguro H, Uemura H, Kubota Y, Nagashima Y, Chang YJ, Hu YC, Tsai MY, Yeh S, Messing EM, Chang C. Promotion of bladder cancer development and progression by androgen receptor signals. J Natl Cancer Inst. 2007; 99:558-568.

6. Johnson AM, O’Connell MJ, Miyamoto H, Huang J, Yao JL, Messing EM, Reeder JE. Androgenic dependence of exophytic tumor growth in a transgenic mouse model of bladder cancer: a role for thrombospondin-1. BMC Urol. 2008; 8:7.

7. Wu JT, Han BM, Yu SQ, Wang HP, Xia SJ. Androgen receptor is a potential therapeutic target for bladder cancer. Urology. 2010; 75:820-827.

8. Zheng $\mathrm{Y}$, Izumi $\mathrm{K}$, Yao JL, Miyamoto $\mathrm{H}$. Dihydrotestosterone upregulates the expression of epidermal growth factor receptor and ERBB2 in androgen receptor-positive bladder cancer cells. Endocr-Relat Cancer. $2011 ; 18: 451-464$.

9. Izumi K, Zheng Y, Li Y, Zaengle J, Miyamoto H. Epidermal growth factor induces bladder cancer cell proliferation through activation of the androgen receptor. Int $\mathrm{J}$ Oncol. 2012; 41:1587-1592.

10. Overdevest JB, Knubel KH, Duex JE, Thomas S, Nitz MD, Harding MA, Smith SC, Frierson HF, Conaway M, Theodorescu D. CD24 expression is important in male urothelial tumorigenesis and metastasis in mice and is androgen regulated. Proc Natl Acad Sci USA. 2012; 109:E3588-E3596.

11. Hsu JW, Hsu IW, Xu D, Miyamoto H, Liang L, Wu XR, Shyr C-R, Chang C. Decreased tumorigenesis and mortality from bladder cancer in mice lacking urothelial androgen receptor. Am J Pathol. 2013; 182:1811-1820.

12. Izumi $\mathrm{K}$, Zheng $\mathrm{Y}$, Hsu JW, Chang C, Miyamoto $\mathrm{H}$. Androgen receptor signals regulate UDPglucuronosyltransferases in the urinary bladder: A potential mechanism of androgen-induced bladder carcinogenesis. Mol Carcinogen. 2013; 52:94-102.

13. Li Y, Zheng Y, Izumi K, Ishiguro H, Ye B, Li F, Miyamoto H. Androgen activates $\beta$-catenin signaling in bladder cancer cells. Endocr-Relat Cancer. 2013; 20:293-304.

14. Jing Y, Cui D, Guo W, Jiang J, Jiang B, Lu Y, Zhao W, Wang X, Jiang Q, Han B, Xia S. Activated androgen receptor promotes bladder cancer metastasis via Slug mediated epithelial-mesenchymal transition. Cancer Lett. 2014; 348:135-145.
15. Li Y, Ishiguro H, Kawahara T, Kashiwagi E, Izumi K, Miyamoto H. GATA3 in the urinary bladder: suppression of neoplastic transformation and down-regulation by androgens. Am J Cancer Res. 2014; 4:461-473.

16. Kawahara T, Shareef HK, Aljarah AK, Ide H, Li Y, Kashiwagi E, Netto GJ, Zheng Y, Miyamoto H. ELK1 is upregulated by androgen in bladder cancer cells and promotes tumor progression. Oncotarget. 2015; 6:29860-29876. doi: 10.18632/oncotarget.5007.

17. Zheng $\mathrm{Y}$, Ishiguro $\mathrm{H}$, Ide $\mathrm{H}$, Inoue $\mathrm{S}$, Kashiwagi $\mathrm{E}$, Kawahara T, Jalalizadeh M, Reis LO, Miyamoto $\mathrm{H}$. Compound A inhibits bladder cancer growth predominantly via glucocorticoid receptor transrepression. Mol Endocrinol. 2015; 29:1486-1497.

18. Kawahara T, Ide H, Kashiwagi E, El-Shishtawy KA, Li Y, Reis LO, Zheng Y, Miyamoto H. Enzalutamide inhibits androgen receptor-positive bladder cancer cell growth. Urol Oncol. 2016; 34:432.e15-23.

19. Shiota M, Yokomizo A, Takeuchi A, Imada K, Kiyoshima K, Inokuchi J, Tatsugami K, Ohga S, Nakamura K, Honda H, Naito S. Secondary bladder cancer after anticancer therapy for prostate cancer: reduced comorbidity after androgendeprivation therapy. Oncotarget. 2015; 6:14710-14719. doi: 10.18632/oncotarget.3817.

20. Izumi K, Taguri M, Miyamoto H, Hara Y, Kishida T, Chiba K, Murai T, Hirai K, Suzuki K, Fujinami K, Ueki T, Udagawa K, Kitami K, et al. Androgen deprivation therapy prevents bladder cancer recurrence. Oncotarget. 2014; 5:12665-12674. doi: 10.18632/oncotarget.2851.

21. Miyamoto H, Yao JL, Chaux A, Zheng Y, Hsu I, Izumi K, Chang C, Messing EM, Netto GJ, Yeh S. Expression of androgen and oestrogen receptors and its prognostic significance in urothelial neoplasm of the urinary bladder. BJU Int. 2012; 109:1716-1726.

22. Ide H, Miyamoto H. Steroid hormone receptor signals as prognosticators for urothelial tumor. Dis Markers. 2015; 2015:840640.

23. Shiota M, Takeuchi A, Yokomizo A, Kashiwagi E, Tatsugami K, Kuroiwa K, Naito S. Androgen receptor signaling regulates cell growth and vulnerability to doxorubicin in bladder cancer. J Urol. 2012; 188:276-286.

24. Kawahara T, Ide H, Kashiwagi E, Patterson JD, Inoue S, Shareef HK, Aljarah AK, Zheng Y, Baras AS, Miyamoto H. Silodosin inhibits the growth of bladder cancer cells and enhances the cytotoxic activity of cisplatin via ELK1 inactivation. Am J Cancer Res. 2015; 5:2959-2968.

25. Kelsen D, Alcock N, Young C. Cisplatin nephrotoxicity: Correlation with plasma platinum concentrations. Am J Clin Oncol. 1985; 8:77-80.

26. Wang CY, Cusack JC Jr, Liu R, Baldwin AS Jr. Control of inducible chemoresistance: enhanced anti-tumor therapy through increased apoptosis by inhibition of NF- $\kappa$ B. Nat Med. 1999; 5:412-417. 
27. Ito Y, Kikuchi E, Tanaka N, Kosaka T, Suzuki E, Mizuno R, Shinojima T, Miyajima A, Umezawa K, Oya M. Downregulation of NF kappa $B$ activation is an effective therapeutic modality in acquired platinum-resistant bladder cancer. BMC Cancer. 2015; 15:324.

28. Lee S, Yoon CY, Byun SS, Lee E, Lee SE. The role of c-FLIP in cisplatin resistance of human bladder cancer cells. J Urol. 2013; 189:2327-2334.

29. Torigoe T, Izumi H, Ishiguchi H, Yoshida $Y$, Tanabe M, Yoshida T, Igarashi T, Niina I, Wakasugi T, Imaizumi T, Momii Y, Kuwano M, Kohno K. Cisplatin resistance and transcription factors. Curr Med Chem Anticancer Agents. $2005 ; 5: 15-27$.

30. Stewart DJ. Mechanisms of resistance to cisplatin and carboplatin. Crit Rev Oncol Hematol. 2007; 63:12-31.

31. Galluzzi L, Vitale I, Michels J, Brenner C, Szabadkai G, Harel-Bellan A, Castedo M, Kroemer G. Systems biology of cisplatin resistance: past, present and future. Cell Death Dis. 2014; 4:e1257.

32. Hsieh TF, Chen CC, Yu AL, Ma WL, Zhang C, Shyr CR, Chang C. Androgen receptor decreases the cytotoxic effects of chemotherapeutic drugs in upper urinary tract urothelial carcinoma cells. Oncol Lett. 2013; 5:1325-1330.

33. Polkinghorn WR, Parker JS, Lee MX, Kass EM, Spratt DE, Iaquinta PJ, Arora VK, Yen WF, Cai L, Zheng D, Carver BS, Chen Y, Watson PA, et al. Androgen receptor signaling regulates DNA repair in prostate cancers. Cancer Discov. 2014; 3:1245-1253.

34. Setlur SR, Royce TE, Sboner A, Mosquera JM, Demichelis F, Hofer MD, Mertz KD, Gerstein M, Rubin MA. Integrative microarray analysis of pathways dysregulated in metastatic prostate cancer. Cancer Res. 2007; 67:10296-10303.

35. Lamb LE, Zarif JC, Miranti CK. The androgen receptor induces integrin $\alpha 6 \beta 1$ to promote prostate tumor cell survival via NF- $\mathrm{KB}$ and $\mathrm{Bcl}-\mathrm{xL}$ independently of PI3K signaling. Cancer Res. 2011; 71:2739-2749.

36. Death AK, McGrath KCY, Sader MA, Nakhla S, Jessup W, Handelsman DJ, Celermajer DS. Dihydrotestosterone promotes vascular cell adhesion molecule-1 expression in male human endothelial cells via a nuclear factor- $\kappa \mathrm{B}-$ dependent pathway. Endocrinology. 2004; 145:1889-1897.

37. Campa VM, Baltziskueta E, Bengoa-Vergniory N, GorroñoEtxebarria I, Wesołowski R, Waxman J, Kypta RM. A screen for transcription factor targets of glycogen synthase kinase-3 highlights an inverse correlation of NFKB and androgen receptor signaling in prostate cancer. Oncotarget. 2014; 5:8173-87. doi: 10.18632/oncotarget.2303.
38. Han AL, Kumar S, Fok JY, Tyagi AK, Mehta K. Tissue transglutaminase expression promotes castration-resistant phenotype and transcriptional repression of androgen receptor. Eur J Cancer. 2014; 50:1685-1696.

39. Katsman A, Umezawa K, Bonavida B. Chemosensitization and immunosensitization of resistant cancer cells to apoptosis and inhibition of metastasis by the specific NF- $\mathrm{BB}$ inhibitor DHMEQ. Curr Pharm Des. 2009; 15:792-808.

40. Kim JK, Kim KD, Lee E, Lim JS, Cho HJ, Yoon HK, Cho MY, Baek KE, Park YP, Paik SG, Choe YK, Lee HG. Up-regulation of Bfl-1/A1 via NF- $\kappa B$ activation in cisplatinresistant human bladder cancer cell line. Cancer Lett. 2004; 212:61-70.

41. Sánchez-Pérez I, Benitah SA, Martínez-Gomariz M, Lacal JC, Perona R. Cell stress and MEKK1-mediated c-Jun activation modulate NFKB activity and cell viability. Mol Biol Cell. 2002; 13:2933-2945.

42. Almeida LO, Abrahao AC, Rosselli-Murai LK, Giudice FS, Zagni C, Leopoldino AM, Squarize CH, Castilho RM. $\mathrm{NF} \kappa \mathrm{B}$ mediates cisplatin resistance through histone modifications in head and neck squamous cell carcinoma (HNSCC). FEBS Open Bio. 2013; 4:96-104.

43. Arlt A, Gehrz A, Müerköster S, Vorndamm J, Kruse ML, Fölsch UR, Schäfer H. Role of NF- $\kappa B$ and Akt/PI3K in the resistance of pancreatic carcinoma cell lines against gemcitabine-induced cell death. Oncogene. 2003; 22:3243-3251.

44. Kawahara T, Kashiwagi E, Ide H, Li Y, Zheng Y, Miyamoto $\mathrm{Y}$, Netto GJ, Ishiguro $\mathrm{H}$, Miyamoto $\mathrm{H}$. Cyclosporine A and tacrolimus inhibit bladder cancer growth through down-regulation of NFATc1. Oncotarget. 2015; 6:1582-1593. doi: 10.18632/oncotarget.2750.

45. Baras AS, Gandhi N, Munari E, Faraj S, Shultz L, Marchionni L, Schoenberg M, Hahn N, Hoque M, Berman D, Bivalacqua TJ, Netto G. Identifiation and validation of protein biomarkers of response to neoadjuvant platinum chemotherapy in muscle invasive urothelial carcinoma. PLoS One. 2015; 10:e0131245.

46. Gandhi NM, Baras A, Munari E, Faraj S, Reis LO, Liu JJ, Kates M, Hoque MO, Berman D, Hahn NM, Eisenberger M, Netto GJ, Schoenberg MP, et al. Gemcitabine and cisplatin neoadjuvant chemotherapy for muscleinvasive urothelial carcinoma: Predicting response and assessing outcomes. Urol Oncol. 2015; 33:204.e1-e7. 